\title{
AS VIVÊNCIAS TRAVESTIS E TRANSEXUAIS NO ESPAÇO DOS TERREIROS DE CULTOS AFRO- BRASILEIROS E DE MATRIZ AFRICANA
}

\author{
- TAIANE FLÔRES DO NASCIMENTO \\ - BENHUR PINÓS DA COSTA ${ }^{2}$
}

\begin{abstract}
Resumo: Gênera, sexualidade e religiãa são temáticas pouco discutidas dentro da geografia, e que estão essencialmente ligadas aus estudos marginais da ciência. Entretanto, com a atual expansão e manifestaçães de diferentes expressões de gêneros, quanta manifestações de cunho religiosa no espaça, a ciência geagráfica, aliada as ciências saciais, acompanha a trajetória da saciedade nesta temparalidade, se tornanda uma ciência interdisciplinar e plural. Neste sentida, este artiga tem coma objetiva geral, relacionar a espaço da terreiro de cultas afro-brasileiros e de matriz africana, como lugar de possibilidade de vivência e expressões travestis e transexuais. Salienta-se que a religiosidade afro em todas as suas formas de manifestaçãa, é periférica. A concepçãa de que a espaça sagrada do terreiro constitui relações de expressões de gênero diferenciadas, aparece para a saciedade como uma forma de ramper a linha contínua de padrões heteronormativos.
\end{abstract}

Palavras-chaves: Gênero; Religiãa; Geggrafia

Introdução

Dentre os diferentes espaços e contextos de sua introdução, em âmbito geográfico, os estudos sobre gênero e sexualidade ainda são incipientes, considerando o espaço-tempo em que os estudos se solidificam, e demandam muitas compreensões sobre a sua meta narrativa, pois "durante muito tempo, as existências 
espaciais desses grupos ou de suas ações concretas não foram consideradas "adequadas" como objetos de estudos do campo da geografia” (SILVA, 2009). Neste sentido, este artigo tem como objetivo geral, relacionar o espaço do terreiro de cultos afro-brasileiros e de matriz africana, como lugar de possibilidade de vivência e expressões travestis e transexuais.

A priori, gênero, sexualidade e religião são temáticas pouco discutidas dentro da geografia, e que estão essencialmente ligadas aos estudos marginais da ciência. Entretanto, com a atual expansão e manifestações de diferentes expressões de gêneros, quanto às manifestações de cunho religioso no espaço, a ciência geográfica, aliada as ciências sociais, acompanha a trajetória da sociedade nesta temporalidade, se tornando uma ciência interdisciplinar e plural.

As travestis e transexuais são sujeitos que apresentam performatividades (BUTLER, 2003) de gênero feminino dissidentes do modelo normativo da mulher binária - o gênero feminino relacionado, tradicionalmente, de forma nata, ao sexo biológico da "femea". De acordo com Butler (2003), há uma construção social historicamente produzida pelas relações de poder que elegeram uma normativa de controle da sexualidade baseada no paralelismo entre sexo biológico, gênero e sexualidade.

Nesta forma paralela, a norma construtora dos padrões normativos de sexualidade é a evidencia da natureza do sexo biológico (macho com pênis e fềmea com a vagina) e a construção dos papéis do homem e da mulher (do masculino e do feminino socialmente falando), assim como a manutenção da heterossexualidade, que fixa as relações sexuais baseadas neste binarismo. No entanto, no esforço teórico de Butler (2003), as plurais dissidências sociais e situacionais das vivências do sexo, do gênero e da sexualidade desvalidam esta norma binária, tornandoa somente um conjunto de signos sociais dogmáticos comumente transgredidos.

No entanto, sujeitos que constroem seus desejos, suas afetividades e seus corpos de forma "transgressora" à norma binária dos sexos e dos gêneros e contra a forma unitária da hegemonia da heterossexualidade (que também se apresenta de forma binária pelo desvio da homossexualidade), são comumente interditados de espaços institucionalizados pelos padrões normativos de gênero e sexualidades.

Os espaços interditos (SILVA, 2009) são inúmeros e tais espaços marginalizam as travestis e transexuais dos processos de convivência, trabalho e lazer sociais. 
Muitas religiões não aceitam em seus dogmas e cultos a expressão de corpos dissidentes dos modelos hegemônicos de gênero e sexualidade. Por outro lado, em outras, as travestis e transexuais são plenamente aceitas e se tormam "espaços possíveis" de expressão de suas feminilidades. Este é o caso dos terreiros de religiões afro-brasileiras, nas quais as travestis e transexuais estudadas neste trabalho se inserem tranquilamente e são aceitas na plenitude da construção de seus gêneros e de suas sexualidades. Neste artigo, iremos discutir as trajetórias teóricas e metodologias da pesquisa estabelecidas com estes sujeitos, assim como os resultados obtidos.

\section{A fenomenologia como método} filosófico e a análise de discurso como método operacional de pesquisa sobre as relações entre gênero e religião na Geografia

Como proposta de método de abordagem da pesquisa, utilizou-se a fenomenologia atrelada ao dispositivo de análise denominado Análise do Discurso (AD), que consistiu basicamente na estrutura abaixo:

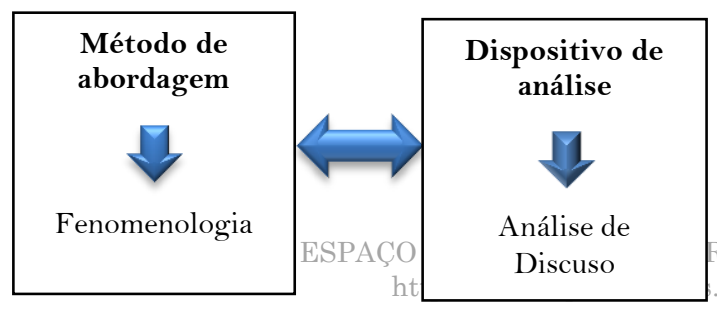

A fenomenologia de modo geral, busca evidenciar as essências repondo-as na existência, na medida em que o concreto sempre existiu "ali", numa forma anterior ao pensamento. A abstração intelectual espaço-temporal do mundo "vivido" materializou-se no exercício descritivo da experiência da maneira como ela ocorre, uma vez que o real deve ser registrado e não construído ou constituído (MERLEAU-PONTY, 1999). Neste sentido, a experiência que constrói o mundo vivido e ela aparece como é observada pelo próprio sujeito.

Nas considerações de Alfred Schutz, em geral, sobre a intencionalidade fenomenológica, destaca-se a fenomenologia do mundo social. Segundo Schutz (1979), Husserl aponta a vida cotidiana como um espaço da vida natural, ou seja, um espaço onde as pessoas se relacionam com os objetos as quais a intencionalidade está alcançando-as. Schutz ressalta ainda, que a importância do significado é dada pela experiência passada que a pessoa possui sobre um fato. Quando o autor fala em fenomenologia do mundo social, instrumenta para as ciências sociais o método husserliano com o objetivo de compreender os mecanismos e de identificar as práticas e os significados sociais e subjetivos que os indivíduos 
manifestam nas interações cotidianas. As noções de contexto, de ação, de convivência e de interação passam a ser importantes à investigação dos rituais, indetermina e das racionalidades subjacentes à vida cotidiana dos indivíduos.

As pontuações de Schutz são importantes para a ciência geográfica, quando associa experiência, interações sociais com o mundo vivido. Neste contexto, faz-se um salto na evolução do conceito fenomenológico, atraindo para a ligação com o espaço, que é uma das categorias de análise da Geografia. A realidade social é produto de interações, da adição de objetos e fatos da vida cultural e social que o senso comum experienciada nas interações. São esses grupos sociais que produzem espaços, os quais são importantes para as análises geográficas.

As análises da fenomenologia na geografia humana têm diferentes abordagens no que se refere ao espaço vivido do indivíduo. Nesta perspectiva, Sokolowski (2004, p. 165) ao introduzir a fenomenologia, diz que

A língua falada, os gestos intencionais e a linguagem corporal imponderável são todos mais do que apenas movimentos corporais; sinalizam atos intencionais, e também expressam conteúdo do pensamento. Expressam para nós como o mundo e as coisas nele aprecem ser para alguém que está naquele corpo. Se a outra pessoa emitir certos sons ou fizer certas caretas, podemos dizer que "lá vêm problemas" ou "não nos abandone agora".

Considera-se na fala do autor, que os elementos importantes na construção do sujeito são visualizados dentro das expressões que o indivíduo apresenta em determinado espaço ou interação com outro indivíduo. Percebe-se desta forma, que a fenomenologia em primeiro momento está atrelada aos estudos culturais dentro da geografia. A cultura como forma de identificação social, pode ser restringida apenas aos valores que cada grupo ou etnia tem e é por essas questões que estudos envolvendo novos grupos sociais vêm se desenvolvendo dentro da geografia, com ênfase nas interações humanas.

Um grupo de fiéis de uma determinada religião, por exemplo, evangélica, que vem se destacando pelo crescente número de seguidores, pode ser considerado um grupo social que produz, organiza ou reorganiza o espaço. São indivíduos que possuem sua própria linguagem, modo de vestir, crenças e 
valores que os diferenciam de outro grupo religioso.

As travestis e as transexuais também são um exemplo concreto de um grupo social construtor de espaços. Sabese que as travestis e transexuais (no feminino, pois é assim que elas gostam de serem enunciadas), possivelmente seja um grupo social recluso de determinados espaços. Elas se destacam no modo de se vestir, no modo de como se comunicam e principalmente no modo em que vivem. Estas expressões de gênero e sexualidade se dão pelos movimentos corporais, em determinados momentos com algo grau de afetividade, estes simbólicos, que as diferenciam enquanto ser social.

A ideia em se trabalhar com novos métodos de abordagem dá maior visibilidade à ciência a se propor em realizar pesquisas que podem ir muito além do conhecimento do pesquisador. Quando ressaltamos esse "além", queremos referir ao sujeito interesse de estudo deste trabalho. Esta no sujeito as respostas em que o pesquisador procura, dando ênfase a sua inteligibilidade como fonte aos estudos. Neste sentido, o positivismo nega a existência dessa fonte, reforçando apenas os fatos encontrados materializados. A fenomenologia dá esse suporte quando Merleau-Ponty (1999, p.01), a conceitua, enfatizando que
[...] é o estudo das essências: a essência da percepção, essência da consciência, por exemplo. Mas a fenomenologia é também uma filosofia que repõe as essências na existência, e não pensa que se possa compreender o homem e o mundo de outra maneira se não a partir de sua "facticidade". [...] É a ambição de uma filosofia que seja uma "ciência exata", mas é também um relato do espaço, do tempo, do mundo vivido. É a tentativa de uma descrição direta de nossa experiência, tal como ela é e sem nenhuma referência à sua gênese psicológica e as suas explicações causais $[\ldots]$ que dela possam fornecer.

Esta linha de pensamento parte do pressuposto de que a consciência só pode ser entendida a partir de sua referência a um objeto, logo, sujeito-objeto difuso na realidade, e é passível de serem analisados distintamente através de uma intencionalidade. No caso desta pesquisa, nossos sujeitos são as travestis e transexuais frequentadoras dos espaços de religiões de matriz africanas conhecidas a partir de um árduo processo de aproximação da pesquisadora. Estes sujeitos de pesquisa, ao mesmo tempo em que transitam por diferentes espaços, também, por sua condição marginal frente a uma sociedade e espaço social 
heteronormativo, são interditadas da vivência de muitos outros. As interdições são, sobretudo, relacionadas aos espaços das religiosidades cristãs, como igrejas católicas e evangélicas, mas, ao contrário, suas vivências são possibilitadas à religiosidades de matriz africana, em terreiros e umbanda e candomblé. Assim, esta pesquisa procura entender as relações intrínsecas entre as formas de expressão de gênero e sexualidade dissidentes das travestis e transexuais e a fé e a inserção aos cultos e atividades místicas das religiosidades afro-brasileiras. As intencionalidades a serem estudadas se referem a dos corpos travestis e transexuais e seus envolvimentos em terreiros de cultos daquelas religiosidades. Nosso esforço é entender a consciências destes sujeitos em relação ao objeto espacial do terreiro, que repercute em suas condições existenciais singulares e suas identidades como sujeitos transgêneros em uma sociedade construída hegemonicamente pela centralidade da heterossexualidade e definição de corpos e papéis binários de gênero atrelados ao sexo biológico. Para isto, utilizamos a “análise de discurso" a fim de adentrar aos significados destes sujeitos aos espaços de relações e cultos das religiosidades afrobrasileiras.

Considera-se a Análise do Discurso (AD) como uma possibilidade de captar o sentido não explícito no discurso. Neste sentido, a interpretação da linguagem propriamente dita vem como uma forma de aproximação sujeito-pesquisador, pois é nesse espaço da linguagem que se podem explicar diferentes fenômenos e conceitos, sendo a palavra uma condição de ponte difundida entre um ou mais locutores e um ou mais interlocutores.

Pode-se considerar que a palavra é o modo mais autêntico e também legítimo das relações sociais, configurando-se como um fenômeno ideológico por excelência. Neste sentido, destaca-se Orlandi (2013, p. 15) quando diz que
A Análise de Discurso, como seu próprio nome indica, não trata da língua, não trata da gramática, embora todas essas coisas lhe interessem. Ela trata do discurso. E a palavra discurso, etimologicamente, tem em si, a ideia de curso, de percurso, de correr por, de movimento. $\mathrm{O}$ discurso é assim palavra em movimento, prática de linguagem: com o estudo do discurso observa-se o homem falando.

Quando Orlandi defende a ideia de que o discurso está sempre em construção, ela se remete aos pressupostos fenomenológicos, pois o discurso se torna 8, P.181-204, JUL./DEZ. DE 2015 
um fenômeno ideológico, que está em constante movimento. A autora ao mencionar em suas palavras o "homem", ela se refere ao homem em geral, o homem como espécie humana, desconsiderando o gênero, ou seja, ela sugere que a $\mathrm{AD}$ conceba a linguagem como mediação necessária entre o homem e a realidade natural e social (ORLANDI, 2013).

Para se trabalhar com esta técnica de análise é importante considerar a linguagem exteriorizada do sujeito, uma vez que ela pode refletir as ideologias levando em conta o sentido, enquanto simbologias constituídas do próprio indivíduo e sua história. Para tanto, destaca-se as observações de Orlandi (2012, p. 83) sobre a questão da materialização do corpo, ou ainda, sobre o processo de significação do mesmo

Considerando a materialidade do sujeito, o corpo significa. Em outras palavras, a significação do corpo não pode ser pensada sem a materialidade do sujeito. $\mathrm{E}$ vice-versa, ou seja, não podemos pensar a materialidade do sujeito sem pensar em relação com o corpo. Por isso nos interrogamos: como juntar corpo, sujeito, sentido, pensado a questão da materialidade discursiva?

$\mathrm{Na}$ perspectiva da autora, é possível perceber que há, mesmo intimamente, um interesse em relacionar a subjetividade do sujeito (o que se torna fenomênico) e a ideologia na análise do discurso. Quando a autora fala em materialidade do corpo, ela faz uma relação entre sujeito/corpo/linguagem/sociedade, visando compreender o discurso, pensando na sua historicidade, dando significado em um ou outro espaço de existência, considerando o espaço de vivência. Neste sentido, Orandi (2013, p. 21) destaca

Para a Análise de Discurso, não se trata apenas de transmissão de informação, nem há essa linearidade na disposição dos elementos da comunicação, como se a mensagem resultasse de um processo assim serializado: alguém fala, refere-se alguma coisa, baseando-se em um código, e o receptor capta a mensagem, decodificando-a.

Trazendo essa "fórmula" que a autora destaca para a realidade da pesquisa, tem-se:

- Alguém fala $=$ travestis e transexuais

- Refere-se alguma coisa baseando-se em um código $=$ questões relacionadas as suas vivências ou não nos terreiros de cultos afro-brasileiros e de origem africana

- Receptor capta a mensagem, decodificando-a $=$ pesquisador grava o curso, compreende a fala e os gestos e o interpreta 
O quadro pode ser entendido como uma forma resumida da proposta da pesquisa, porém a $\mathrm{AD}$ discutida por Orlandi (2013) possibilita que esses segmentos não precisam estar nesta ordem propriamente dita, pois não há separação do emissor e receptor. Neste sentido, esses três elementos, podem estar relacionados criando um efeito de sentidos entre os locutores, ou seja, criando uma regularidade que só funciona se não ocultar deste mecanismo, o social e o histórico, o sistema em que tal sujeitos estão inseridos. Para tanto, considera-se que a $\mathrm{AD}$ seja a chave de interpretação de diferentes produções de sentidos da fala, da linguagem, gestos e tudo que o pesquisador conseguir interpretar diante de um discurso.

A estrutura metodológica representativa remete a fenomenologia pois considera-se que é uma situação em que sujeitos estão se envolvendo com algo: uma vivência, uma experiência e suas subjetividades estão em relação. A AD como busca das ideologias e representações que se repetem é um engessamento teórico-metodológico à pesquisa, pois pode-se utilizá-la para entender as subjetividades dos sujeitos.

\section{Breve contextualização sobre a relação} Gênero, Sexualidade e Religião

Judith Butler é um dos grandes nomes dos estudos de gênero, sexualidade e também queer no cenário acadêmico mundial. Ela traz para a contemporaneidade, os estudos envolvendo outra noção de gênero como os gays, lésbicas, transexuais e novas identidades homossexuais, que foram invisibilizadas ao longo do tempo pelos estudos feministas. Para ela, essas outras identidades sexuais desestabilizam as outras, sejam homo ou heterossexuais. Neste sentido, destacam-se as palavras de Butler (1990, p.7)

O gênero pode também ser designado como o verdadeiro aparato de produção através do qual os sexos são estabelecidos. Assim, o gênero não está para a cultura como o sexo para a natureza; o gênero é também o significado discursivo/cultural pelo qual a 'natureza sexuada' ou o 'sexo natural' é produzido e estabelecido como uma forma 'pré-discursiva' anterior à cultura, uma superfície politicamente neutra sobre a qual a cultura age.

Argumentando posteriormente que o gênero Butler (2008, p. 58) 
[...] é a estilização repetida do corpo, um conjunto de atos repetidos no interior de uma estrutura reguladora altamente rígida, a qual se cristaliza no tempo para produzir a aparência de uma substância, de uma classe natural de ser.

Neste sentido, seguindo o pensamento de Butler, o gênero não é um conjunto de significados culturais impressos num corpo nem a interpretação cultural de um corpo sexuado, e também ser do sexo masculino ou ser do sexo feminino não constituem uma essência interior do indivíduo, mas sim, um conjunto de normas fundamentadas sobre o corpo que geram essa aparência de substância e torna o indivíduo livre.

A autora, traz em seu livro "Problemas de Gênero: feminismo e subversão da identidade" de 2003, a desconstrução do gênero. Pensa as ficções sociais que produzem desigualdades nos processos de produção de diferenças identitárias. Butler desconstrói essa meta narrativa sobre a perspectiva do corpo, ressaltando que a representação de gênero é fragmentada, onde a diferença está no próprio corpo. Um exemplo são as travestis, que não executam a masculinidade. Ele subverte o padrão de gênero, onde desestabiliza esta norma e dá movimento à estrutura, tornando possível a possibilidade de pluralidades.

A divisão de gênero funciona como uma espécie de pilar fundamental da política feminista e parte da ideia de que o sexo é natural e o gênero é socialmente construído. Butler vai problematizar essa premissa, onde discutir essa dualidade é o ponto de partida para que a autora debatesse o conceito de mulheres como sujeito do feminismo. Uma das maiores preocupações de Butler seria o fortalecimento das teorias queer ${ }^{4}$ dos movimentos de gays, lésbicas e transgêneros e de certo abandono do feminismo como um campo ultrapassado. Pelas considerações de Judith Butler (2003, p. 39-40)
A heterossexualização do desejo requer $\mathrm{e}$ institui a produção $\mathrm{e}$ oposições discriminadas e assimétricas entre "feminino" e "masculino", em que estes são compreendidos como atributos expressivos de "macho" e "fêmea". A matriz cultural por intermédio da qual a identidade de gênero se torna inteligível exige que certos tipos de "identidade" não possam "existir" [...]

A autora destaca que a identidade é uma categoria importante na construção de um pensamento baseado na temática 
em questão, por apresentar diferentes formas de entendimento e compreensão. Ela evidencia o mecanismo de gênero em sua primeira parte da obra e destaca que o feminismo pressupõe a existência de uma identidade feminina, ou seja, o estabelecimento de uma linguagem pressupõe a busca da visibilidade feminina. A crítica feminista tem de explorar as afirmações totalizantes da economia significante masculina, mas também deve permanecer autocrítica em relação aos gestos totalizantes do feminismo (BUTLER, 2003).

Os debates feministas contemporâneos sobre o essencialismo ressaltam de outro modo a questão da universalidade da identidade feminina e da opressão masculina. Esta abordagem universalista é baseada em um ponto de vista epistemológico comum ou compartilhada, como estruturas compartilhadas de opressão. Neste sentido, Butler (2006, p. 59) destaca que

O gênero é o mecanismo pelo quais as noções de masculino e feminino são produzidas e naturalizadas, mas ele poderia ser muito bem o dispositivo pelo qual estes termos são desconstruídos e desnaturalizados.

As travestis e transexuais como exemplo de desconstrução do gênero, questionam a linearidade do mecanismo de gênero, pois é considerável que o gênero é constituído a partir das práticas sociais, ou seja, os corpos das travestis e transexuais contrariam as normas de linearidade entre sexo/gênero/desejo. Neste sentido, o gênero é um fenômeno constante e contextual, ou seja, resultado da relação de espaço/tempo/relações sociais, ou ainda, o espaço é permeado por relações de gênero e estas se ressignificam nas relações socioespaciais cotidianas.

Compreender os grupos marginalizados da sociedade heterossexual normativa, nas relações de gênero, vivenciadas no contexto da religiosidade principalmente de origem africana e afro-brasileiras, é um desafio à ciência geográfica. Por se tratar de temáticas também marginalizadas e pouco discutidas em âmbito acadêmico, o desenvolvimento de uma meta narrativa que possa construir conceitos, fica a deriva em estudos geográficos.

A busca do fenômeno espacial, em que as travestis e transexuais se destacam atualmente, seja ele relacionado a territórios de poder ou espaços religiosos, ressalta a ideia da subjetividade do sujeito, na vivência de espaços possíveis ou não a diferentes expressões de gênero. $\mathrm{Na}$ formação cultural da sociedade brasileira, a influência da religiosidade é um fator 
indiscutível, produzindo padrões de subjetividades masculinas e femininas, normatizando e estabelecendo formas de controle sobre a sexualidade, principalmente no que se refere as relações afetivas. $\mathrm{O}$ surgimento da diversidade religiosa não tem se mostrado suficiente para alterar a hegemonia do modelo normativo dessas relações e reduzir a marginalização daqueles que não se encaixam nos padrões estabelecidos pela sociedade normativa. Portanto, a temática de gênero e sexualidade, juntamente com a intercessão do padrão heterossexual das relações, se mantêm como uma questão de confluência entre a maioria dos grupos religiosos como um todo.

O acréscimo da diversidade religiosa não tem se mostrado suficiente para decompor a hegemonia da normatividade de relações afetivas e sexuais. Ainda não reduzem a discriminação àqueles que vivenciam formas alternativas de identidade e orientação sexual, porém não se pode generalizar, uma vez que algumas religiões procuram ser mais abertas as questões relacionadas a opção sexual de cada adepto ou fiel que a cultua. As religiões têm, explícita ou implicitamente, em sua estrutura teológica e prática institucional e histórica, uma visão peculiar de cunho antropológico que constitui e delimita os papéis de gênero (masculinos e femininos). $\mathrm{O}$ embasamento dessa visão encontra-se em uma ordem talvez indiscutível, por estar em forma de dogmas. À medida que as expressões da sociedade surgem, as religiões reproduzem sua ordem de valores, que refletem em seu discurso, sob o pretexto da revelação divina.

Rosendahl (1996) enfatiza que, os estudos realizados com a temática geografia da religião, possuem diversos sentidos de análise, que incluem a diversidade dos fenômenos religiosos e as inúmeras possibilidades que buscam explicar a expansão de diferentes religiões no espaço e no tempo. Neste sentido, analisar religião não está apenas em enfatizar a fé, mas também evidenciar as possibilidades de relações sociais que os espaços simbólicos constituem diante dos indivíduos que dividem a mesma crença. Sobre essa questão, destaca-se as considerações de SOUZA (2004, p. 122123)

A religião é, antes de tudo, uma construção sócio-cultural. Portanto, discutir religião é discutir transformações sociais, relações de poder, de classe, de gênero, de raça/etnia; é adentrar num complexo sistema de trocas simbólicas, de jogos 
de interesse, na dinâmica da oferta e da procura; é deparar-se com um sistema sócio-cultural permanentemente redesenhado que permanentemente redesenha as sociedades.

Ao enfatizar a relação da religião com as transformações sociais, no nosso caso, as que envolvem o gênero, sugere-se discussões que possam identificar a influência dos padrões normativos diante de uma nova visão sobre a diversidade. A religiosidade afro integra todas essas discussões, uma vez que todas elas fazem parte de seu universo fundamentalista. Um exemplo importante a ser considerado sobre diversidade de gênero, está atrelado aos grupos queer dentro dos terreiros de cultos afro-brasileiros e de matriz africana. As travestis e transexuais são grupos sociais excludentes das convenções da sociedade, onde ser normal, é ser heterossexual.

Partindo da perspectiva de que a religião é uma temática de cunho social, com uma gama de significações espaciais, durante muito tempo não interessou aos estudos geográficos, deixando as ciências sociais se apropriarem, contribuindo fundamentalmente, para a compreensão do fenômeno. Na visão de Rosendahl (1996), a influência positivista na geografia e a irrelevância da temática para a Geografia Crítica funcionaram como complicadores para que isso acontecesse, tal fato justifica a aproximação da religião a Geografia Cultural e Humanista, duas tendências geográficas baseadas nos estudos humanos e sociais. Neste sentido, destaca-se a noção introdutória desses estudos, nas palavras de GIL FILHO (2007, p. 208)

O homem no seu processo de adaptação com o meio marca a terra a partir de seu pensamento atribuindo sentido às realidades naturais e sobrenaturais. Deste modo o homo faber sapiens torna-se o homo religiosus. Em razão deste aspecto é necessário que uma parte da Geografia Humana estude o homem sob à influência da religião, ou seja, uma Geografia das Religiões.

A geografia na sua perspectiva humanista e também cultural pode ser capaz de explicar essas relações de subversão e/ou de acolhimento por parte de grupos religiosos no que se refere a introdução desses grupos sociais marginalizados da sociedade heteronormativa. É importante ressaltar que os estudos do fenômeno religioso 
estão atrelados a estas duas tendências, pois ainda se baseiam em códigos culturais de determinado grupo social para explicar as manifestações religiosas no espaço. Neste sentido, ressaltarei algumas premissas que possam justificar a necessidade de um olhar geográfico em se debruçar na temática de gênero e sexualidade para analisar a atual configuração espacial de forma que o próprio espaço sagrado seja possível principalmente aos grupos queer. Sob esta perspectiva de se analisar o fenômeno religioso a partir das realidades sociais, Claval (1999, p. 53) afirma:

Insistindo sobre o sentido dos lugares, sobre a importância do vivido, sobre o peso das representações religiosas, torna indispensável um estudo aprofundado das realidades culturais. É necessário conhecer a lógica profunda das ideias, das ideologias ou das religiões para ver como elas modelam a experiência que as pessoas têm do mundo e como confluem sobre sua ação.

Quando Claval fala em "experiências das pessoas", mesmo que ocultamente, está falando em indivíduos sem destacar o gênero e/ou sexualidade. Ele traz a ideia de que essas ideologias, dogmas de uma religião pode influenciar nas ações do sujeito, refletindo nas suas relações estabelecidas socialmente. A partir desta perspectiva, uma das possibilidades diante da composição do espaço religioso por relações sociais diferenciadas de gênero e também de sexualidade pode ser relacionada diante de uma análise de discurso e também cultural dos pressupostos da diferenciação de crenças. A partir da premissa de que a religião é uma forma de conhecimento relativo, é possível entendê-la como dinâmica e diversificada. (GIL FILHO, 2008). Neste sentido, é possível relacionar as religiões como possíveis espaços interditos ou não-interditos às diferentes relações e expressões de gênero e sexualidade. A partir desta ideia, Lemos (2005, p. 26) considera que

A religião continua em cena porque o ser humano precisa dela para se localizar num mundo dotado de significado e para se entender como parte de um cosmos. Ou seja, o indivíduo para entender a si mesmo, compara-se com outros, com valores, instituições e com os significados presentes na sociedade. Caso não consiga se localizar em relação ao lugar que ocupa no seio da sociedade, sente-se ameaçado de perder os laços que o satisfazem emocionalmente, a 
sua orientação na experiência da vida, ou seja, sente-se ameaçado de anomia.

Tendo em vista as considerações de Lemos acerca da procura do homem pela fé, sugere-se que se os grupos queer sentem-se fora dos padrões, considerando que a religião possa dar sentido à vida dos sujeitos, talvez seria possível compreender que a presença de uma religiosidade focada aos grupos exclusos da sociedade normativa, é uma tentativa do que se poderia chamar de liberdade assumida da negação de um padrão dominante.

\section{Os discursos das travestis e transexuais: afirmação ou desmistificação?}

As vivências travestis e transexuais nos terreiros de cultos afrobrasileiros tem como resultado da marginalização tanto dos grupos queer, quanto da religião, que ainda está em processo de afirmação na sociedade brasileira. A pesquisa encontrou nos discursos, a aproximação dos sujeitos travestis e transexuais com a religiosidade afro, em diferentes perspectivas. Ao serem questionadas sobre a aproximação com a religiosidade afro, obtivemos as seguintes respostas:
Eu sempre fui de religião, e não tenho um terreiro fixo. Vou onde tem festas e que sei que sou bem-vinda. $\mathrm{Na}$ verdade, decidi assim por que se uma mãe (de santo) descobre que estou indo em uma casa que ela não gosta, depois vira fofoca. Então prefiro assim mesmo, sem estresse, sem problema, apenas curtindo os "bafos" ${ }^{5}$ [...] (Maria)

[...] eu vivia sempre sem nada, não tinha essa coisa de acreditar em nada, já tinha perdido todos os créditos, digamos assim. Ai foi quando eu reencontrei uma amiga que é trans, a gente se reencontrou depois de muitos anos, e ai eu não estava ainda no processo de mudança, e ela me convidou: "vamos lá, tenho que visitar meu pai de santo, faz muitos anos que não venho ao Brasil, eu quero ir lá e tu quer ir junto comigo?”, ai eu disse: “vou, vamos, né? O que há, né?” Cheguei lá, fui muito bem recebida, aquela coisa toda, vi que também era uma trans e aí depois teve outro momento que fui numa festa de religião lá, aí um dia eu disse que queria jogar os búzios. E aí ela jogou os búzios para mim, essa que é pai de santo, que hoje é mãe de santo também. Aí ela jogou os búzios e parecia que ela estava desvendando toda minha história, coisas que eu não tinha nunca falado pra ninguém, coisas minhas, coisas muito 
individuais, enfim, parece que ela havia aberto um livro da minha vida. Dai eu fiquei impressionada com aquilo e comecei a frequentar, ir lá e tal. Na época que ela jogou os búzios, ela disse que "tu não tem, atualmente tu tá perdido, sem nenhuma crença, a pessoa precisa ter uma crença superior, coisa e tal. Mas tu fica livre. Tu tens dois caminhos, ou tu segue essa vida que tu tem, ou tu segue o outro caminho que é o da religiosidade". Então foi isso. $\mathrm{Na}$ verdade, eu me aproximei através de uma amiga para essa religião e ai comecei então a frequentar aos pouquinhos, mas sempre com aquele olhar observador, né? De não cair direto, por que tu sabe, a gente fica com o pé atrás com algumas coisas, né? $\mathrm{E}$ aí foi quando comecei a frequentar. (Flor)

Maria não entrou em muitos detalhes sobre sua inserção dentro dos terreiros, mas salientou que prefere em ir em todos conhecidos e não assumir o compromisso que a religião propõem, em nenhum. Salienta que gosta de terreiros onde ela é bem-vinda, coisas aparentemente típicas de indivíduo adepto e que vê na religiosidade afro, um lugar para estabelecer relações de amizade, afetiva e até mesmo de diversão.
Com base no segundo discurso apresentado, detalhou-se a primeira experiência de Flor dentro da religião, que foi através de uma amiga, a qual abriu a oportunidade da mesma conhecer afundo o modo de como se apresentavam as religiões afro. De certa forma, foi um olhar primeiro da entrevistada, sendo que, ela mesma, inicia seu discurso salientando que não acreditava em nenhuma crença. Essa primeira impressão sobre a religiosidade a qual teve Flor, foi o ponto de partida para que ela percebesse outras questões que poderiam dizer muito mais sobre ela mesma. Os búzios, a que se referiu, foi uma forma de apresentação de caminhos e relações que Flor poderia alinhar na sua compreensão sobre o que seria a crença. Isto fica evidente, quando ela diz que

Bom, aí depois, que eu fiz o primeiro ritual, parece que deu uma mudança, mas também eu posso te dizer, que foi através dali que eu tive um pouco de autoconfiança, até para começar a construir essa minha identidade, começar a ter coragem de sair do armário e toda aquela história, então quer dizer, foi também através da religião que eu tive força em acreditar que era possível. E tanto é que assim, lembro como se fosse hoje, eu fui no dia 23 de junho, fui lá na casa dela, lavei minha cabeça na verdade, fiz minha primeira obrigação com ervas, lavei com omieró ${ }^{5}$ e tal, e no dia 24 sai de lá. Fiquei um dia lá dentro da terreira. E 
ai eu sai de lá assim pensando "bom, agora o que mais eu vou fazer?", parecia que tinha, não digo que foi isso, entendeu? Mas aquilo me fez despertar para outras questões. Isso foi em junho, e dali em diante não parei e minha vida mudou totalmente. (Flor)

Para Flor, a crença referida nas religiões afro, foi de extrema importância na construção de sua identidade e o modo de como sua vida passou por diversas transformações. Essa intensa ligação, pode ser relativizada como os parâmetros hegemônicos da religiosidade afro, ajuda na construção do sujeito em seu norteamento enquanto ser social. Nesta perspectiva, é importante ressaltar que o desenvolvimento da identidade religiosa está condicionado a uma determinada temporalidade e espacialidade e perpassa o reconhecimento institucional da religião. (GIL FILHO, 2008).

Ainda sobre esta perspectiva da aproximação com a religiosidade afro, destacamos outros três discursos diferentes no que se refere a inserção em terreiros de cultos afros.

Eu nasci em uma família de mãe católica e pai umbandista, sempre tive contato com as religiões de matriz africana. Em 2008 quando me senti preparado para seguir “compromissadamente” uma religião, eu entrei para a Nação africana. (Rosa) Amiga, metade da minha família já era da religião, mas nunca tinha me identificado, chegou um momento que sei lá... Algo me chamou, sabe? E fui me identificando, então hoje sou da Umbanda e da Nação. (Rafaela)

Olha... Nasci e me criei dentro da religião, meus avós eram de religião. $\mathrm{Eu}$ sou a sexta geração de minha família herdando nosso Terreiro. Agora tenho meu próprio Terreiro, mas o de meus pais ainda está aberto com direção de minha cunhada e primos. $\mathrm{O}$ afro é tudo pra mim, meu orixá Oyá é a força de minha vida. (Beta)

Nestes três discursos, percebe-se a semelhança de aproximação dos sujeitos com a religiosidade. Os três sujeitos já estavam inseridos, mesmo que não assiduamente, na religião. As três entrevistadas são filhas de adeptos, e isso facilitou, pelas palavras acima, a identificação com os cultos. É importante destacar que a Nação em que Rafaela destaca, é um seguimento religioso de origem africano, o qual os médiuns trabalhavam dentro dos terreiros, apenas com orixás. Já a Umbanda, há o sincretismo religioso, onde se reverencia as entidades com os mesmos nomes da religião católica. 
O processo de inserção também pode-se considerar semelhantes, uma vez que as entrevistadas, passaram por um processo de reconhecimento da religiosidade e também esperaram o tempo certo de assumir os compromissos que ela exige. Como fundamentos das religiões afro, uma das questões é a preparação psicológica para enfrentar os desafios propostos por ela. Rosa, ao evidenciar a palavra "compromisso", trás a ideia dessa preparação e Rafaela, ao destacar a "identificação", declara o seu aprofundamento dentro da religião afro.

Destacamos também o discurso de Lola, onde ela diz que,

$\mathrm{Na}$ verdade, eu tenho 25 anos de religião. Eu comecei, eu tinha quatorze, treze para quatorze anos e foi por intermédio de uma colega de escola, por que a família dela era da casa de umbanda, né? E eu ia, me identifiquei. Na época eu tinha vários problemas de agitamento, de não dormir direito, né? E a mãe me levava para consultar e os médicos nunca achavam nada e na verdade o que eu tinha era uma mediunidade muito forte. Aí eu entrei e inclusive não foi fácil no começo porque, foi escondido do meu pai, principalmente, e minha mãe sempre soube de tudo, inclusive da minha própria sexualidade. Então me escondi de início do meu pai e meu pai me tirou de casa, tive um tempo fora, depois deu certo tudo, mas eu comecei muito cedo na religião. (Lola)

A aproximação de Lola é um caso muito especial que envolve muitas das transexuais e travestis na religiosidade afro. Em sua fala, ela destaca que sofria de problemas como insônia e agitação e que isso era resultado de sua mediunidade. Aqui abro um parêntese que considero interessante. Quando nos interessamos por essa temática, prevíamos que nos discursos, as travestis e transexuais procurassem a religião afro com o objetivo de se tratarem de alguma enfermidade.

Ao serem questionadas se a religião mudou algo em suas vidas, elas respondem com euforia e emoção, através de gestos espontâneos. A perspectiva das respostas é diferente, porém a ideia de emoção pode ser considerada a mesma, na medida em que elas ressaltam a importância da religião em suas vidas:
Mudou muito! Pois eu por ter mãe católica e pai umbandista via o quanto a igreja católica demonizava os homossexuais e as religiões de matriz africana não, pois as religiões afro não colocam a orientação sexual como um tabu. Inclusive na nossa religião temos divindades que são homossexuais. (Rosa) 
Nossa! A religião foi meu porto seguro. Foi tudo na minha vida. Com ela aprendi muitas coisas e conheci muitas pessoas que até estão em minha vida. (Rafaela)

O afro é tudo para mim, meu orixá Oyá é a força de minha vida. Há muito preconceito, ninguém dá chance a trans ou travestis. Graças a Deus e aos orixás tenho outra renda e um bom marido. (Beta)

[...] foi através dali que eu tive um pouco de autoconfiança, até para começar a construir essa minha identidade, começar a ter coragem de sair do armário e toda aquela história, então quer dizer, foi também através da religião que eu tive força em acreditar que era possível. [...] Foi assim, uma mudança radical, que no outro ano em junho, eu já tinha ido pra Europa, eu já tinha assumido minha identidade, já tinha feito minha cirurgia e desde aquele período, um ano depois, muita coisa mudou, muita coisa aconteceu. Inclusive, não digo financeira, mas parece que abriu várias possibilidades, tanto no mundo assim... Então foi isso, basicamente. (Flor)

A questão da religiosidade na vida das quatro travestis e transexuais está muito presente. O terreiro pode ter sido uma forma de integração muito maior e de possibilidades de relações sociais. Nesse sentido, ele é posto em evidência, mesmo que ocultamente, como um mecanismo que regularia o próprio papel das entrevistadas do mundo. Rosa, ao referirse sobre as "divindades homossexuais", descobrimos um ponto positivo a mais que leva a Umbanda, Quimbanda e Nação como possíveis as diferentes expressões de gênero. A afirmação de que há entidades homossexuais nas religiões afro, ainda é uma discussão que não tem um embasamento teórico-filosófico que concretize as suas existências, pois são suposições dos sujeitos que cultuam a religião.

Possível explicação para essa discussão está aquela ligada a espiritualidade em si, onde muitos espíritos estão sendo revelados em diferentes manifestações dentro do terreiro. Há quem diga que, com o passar do tempo, alguns espíritos não chegam mais a terra e no lugar, são enviados outros. Neste sentido, não se sabe o número certo de entidades que fazem parte das religiões afro, mas sabe-se que os espíritos se renovam e que podem ser velhos ou novos. Beta e Rafaela foram objetivas em relatar que a religiosidade foi tudo em suas vidas, porém era perceptível em seus gestos, sentimentos e emoções demonstrados juntos das palavras. Pode- 
se dizer que a religião, foi a base para a construção de suas vidas.

Destacando então, o discurso de Flor, onde a religiosidade foi um dos elementos principais para que a travesti "saísse do armário", fica evidenciado a intrínseca relação do sujeito com a fé. Para ela, a religiosidade não foi apenas um lugar de relações sociais, mas também de encontro com si mesma. Isso a ajudou no processo de identificação, ressaltando ainda mais sua orientação sexual, afirmando a sua identidade enquanto homossexual. Ao salientar a religiosidade em sua vida é possível entender que as religiões afro-brasileiras e de origem africana podem se tornar um espaço possível às vivências travestis e transexuais em qualquer ocasião, seja em rituais de passagens (festas), ou como membro do terreiro.

\section{Questionadas sobre a presença das travestis e transexuais nos terreiros de cultos afros, obtivemos as seguintes respostas:}

Felizmente é a religião que recebe a gente, homossexuais, de braços abertos sem preconceitos. [...] por que na realidade o que importa é o respeito e o fundamento, e eles tornam tudo igual, sem distinção de sexo e gênero. (Rafaela)
Amore, o que eu entendo sobre a opção das trans e das travestis escolherem a religião africana, umbanda e candomblé seria a boa aceitação delas nessa religião. Existe até rituais de união homoafetiva, festas lindas. Também tem a quimbanda, que lida mais com o lado magia negra, exus e pomba giras [...] (Maria)

Considerando que as religiões afrobrasileiras e de origem africana são diferenciadas nesta perspectiva de gênero, é possível salientar duas expressões básicas que assumem forma de valorização do que se refere a identidade dos sujeitos: "não define sexualidade" e "braços abertos sem preconceitos". Essas expressões importantes na construção desse trabalho, é uma forma de manifestação a favor da religiosidade afro. $\mathrm{O}$ terreiro, inicialmente como espaço, é tido como o lugar, posteriormente, de relações sociais, as quais se caracterizam pela própria identificação religiosa citada pelas entrevistadas. Ainda que as duas sejam filhas de umbandistas/quimbandistas/adeptos a Nação, não se pode considerar um elemento único para suas inserções dentro do terreiro. A identificação também pode estar relacionada com o modo em que a religião as acolheu e acolhe. É um modo 
primeiro de estabelecer uma experiência dentro da mesma, através de sentimento de pertencimento.

Ao longo da pesquisa, descobrimos que o espaço do terreiro, além de ser aberto as expressões das travestis e transexuais também é fundamental na construção da identidade do sujeito, seja ele heterossexual ou homossexual, e que a desconstrução do gênero é sempre uma meta pela qual a maioria dessa população religiosa, propõem dia após dia. Para isso, ressalta-se as considerações de Birman (2005, p. 404)

É possível melhorarmos significativamente a compreensão que temos sobre as relações de gênero e o espaço concedido à sexualidade nesses cultos. Isso porque poderemos olhar com menos constrangimentos teóricos e, quiçá, teológicos as delicadas relações que se tecem quando a prática da possessão entrelaça humanos, deuses e espíritos em tramas que envolvem desejos sexuais, elos afetivos e papéis de gênero com os diferenciais de poder que atravessam todas essas inter-relações.

E as considerações de Santos (2013, p. 17), onde conclui que

O candomblé aparece como um espaço ambíguo por oferecer em alguns casos o acolhimento ao modo de ser e viver das travestis e mulheres transexuais e, em outros casos, reproduzindo os papéis de gênero e sexuais vigentes, lhes impõe uma forma engessada de cultuar os orixás, fazendo com que muitas pessoas trans desistam da vida religiosa, mas leve para outros espaços de sociabilidade trans, a cultura, a linguagem e os costumes aprendidos na vivencia do candomblé.

Com base nas palavras de Birman e considerando as experiências de vidas das transexuais e travestis aqui enunciadas, considera-se parcialmente que ainda assim as religiões afro-brasileiras e de origem africana têm sido procuradas por esses sujeitos, uma vez que, mesmo com diferentes formas relações estabelecidas entre elas, oferecem um espaço possível para que possam expressar a sua religiosidade tentando associar com a sua identidade de gênero.

A religiosidade afro é marginalizada e estigmatizada por integrar a diferença entre expressões de gênero. A ideia de que o espaço sagrado do terreiro estabeleça relações diversas, surge para a sociedade como uma forma de desconfigurar a linearidade da padronização produzida e estabelecida na matriz cultural brasileira.

\section{Considerações finais}


A geografia humana, juntamente com a perspectiva queer pode ser capaz de explicar essas relações de subversão e/ou de acolhimento por parte de grupos religiosos no que se refere a introdução desses grupos sociais marginalizados da sociedade normativa. A partir desta perspectiva, uma das possibilidades diante da composição do espaço religioso por relações sociais diferenciadas de gênero e também de sexualidade pode ser relacionada diante de uma análise de discurso e também cultural dos pressupostos da diferenciação de crenças.

Os estudos queer em relação a subjetividade e intersubjetividade das travestis e transexuais, são compostos substancialmente nas suas relações de poder. Paralelo a isso, a fenomenologia poderá ser a opção de um caminho para compreender a relação do ser social travesti e transexual com o espaço em que vivencia e estabelece diferentes relações interpessoais.

O espaço do terreiro, é de afirmação de uma religiosidade cada vez mais marginalizada por integrar diferentes expressões de gêneros, e a crença coloca em evidência, como podemos desatrelar das pesquisas, identidades sexuais e de gênero que transitam entre o reconhecimento aos padrões normativos dominante e a sua transgressão, compreendendo então, que apesar de todas as divergências e dificuldades, esses espaços são possíveis.

\section{NOTAS}

${ }^{1}$ Mestranda do Programa de Pós-graduação em Geografia pela Universidade Federal de Santa Maria (UFSM). Integrante do Laboratório de Espacialidades Urbanas (LABEU) do departamento de Geociências da UFSM. E-mail: tayflores181@yahoo.com.br.

2 Docente do Departamento de Geociências e Programa de Pós-graduação em Geografia pela Universidade Federal de Santa Maria (UFSM). Coordenador do Laboratório de Espacialidades Urbanas (LABEU) do departamento de Geociências da UFSM. E-mail: benpinos@gmail.com.

3 Queer tem inúmeros significados e traduções, porém pode ser considerado estranho, esquisito. Ver em: LOURO, Guacira Lopes. O corpo estranho. Ensaios sobre sexualidade e teoria queer. Belo Horizonte: Autêntica, 2004.

${ }^{4}$ Considera-se uma teoria sobre o gênero onde diz de forma geral, que a orientação sexual e a identidade sexual ou de gênero dos indivíduos são o resultado de uma construção social. Neste sentido, ela defende a ideia de que não existem papéis sexuais essencial ou biologicamente inscritos na natureza humana. Ver em: BUTLER, Judith. Problemas de Gênero: Feminismo e subversão da identidade. Rio de Janeiro: Civilização Brasileira, 2003.

${ }^{5}$ Há inúmeras interpretações para este termo, que a princípio, significa algo que chama atenção. $\mathrm{Na}$ linguagem das travestis e transexuais, "bafo" pode representar acontecimentos divertidos em geral, conflitos, fofocas, brigas e extravagâncias que toda 
travesti e transexual, ou sujeito LGBT gosta, pois remete a desconstrução da normalidade social e do equilíbrio, ou seja, o extravagante e a desconstrução são suas realidades.

${ }^{6}$ Infusão de folhas e ervas utilizadas para banhar pessoas ou iniciados na religião. Ver em: https://books.google.com.br/books?isbn=853140 7427. Acesso em: 23 de abril de 2016.

\section{REFERÊNCIAS BIBLIOGRÁFICAS}

BIRMAN, Patrícia. Transas e transes: sexo e gênero nos cultos afro-brasileiros, um sobrevoo. In: Estudos feministas, Florianópolis, vol. 13(2), 2005.

BUTLER, Judith. Críticamente subversiva. In: JIMÉNEZ, Rafael M. Mérida. Sexualidades transgresoras. Una antología de estudios queer. Barcelona: Icária editorial, 2002, p. 55 a 81.

Problemas de Gênero: feminismo e subversão da identidade. Rio de Janeiro: Civilização Brasileira, 2003.

Défaire le Genre. Paris, Éditions Amsterdam, 2006.

CLAVAL, Paul. A geografia cultural. Florianópolis: Ed. UFSC, 1999.

GIL FILHO, S. F. Geografia da Religião: Reconstruções Teóricas sob o idealismo crítico. In: KOZEL, S.; SILVA, J. C.; GIL FILHO, S. F. (orgs.). Da percepção e Cognição à Representação: Reconstruções teóricas da Geografia Cultural e Humanista. São Paulo: Terceira Imagem; Curitiba: NEER, 2007.

Espaço Sagrado: estudos em geografia da religião. Curitiba: Ibpex, 2008.

LEMOS, Carolina Teles. Religião, gênero e sexualidade: o lugar da mulher na família camponesa. Goiânia: Ed. Da UCG, 2005.

LOURO, Guacira Lopes. O corpo estranho. Ensaios sobre sexualidade e teoria queer. Belo Horizonte: Autêntica, 2004.
MERLEAU-PONTY, Maurice. Fenomenologia da Percepção. São Paulo: Martins Fontes, 1971.

Fenomenologia da

Percepção. Tradução Carlos Alberto Ribeiro de Moura. $2^{\circ}$ Ed. São Paulo: Martins Fontes, 1999.

ORLANDI, Eni Puccinelli. Discurso em Análise: Sujeito, Sentido, Ideologia. Campinas, SP, Pontes, 2012. 239p.

Análise de discurso: princípios e procedimentos. 11 ed. Campinas: Pontes, 2013. ROSENDHAL, Z. Espaço e religião: uma abordagem geográfica. Rio de Janeiro: Eduerj, 1996.

SANTOS, Ailton da Silva. O gênero na berlinda: reflexões sobre a presença de Travestis e mulheres transexuais nos terreiros de Candomblé, In: III Seminário Internacional Enlaçando Sexualidades, 2013, Bahia. Anais... Bahia: III SIES, 2013.

SCHUTZ, Alfred. Bases da fenomenologia. In: WAGNER, H. (Org). (1979) Fenomenologia e relações sociais: textos escolhidos de Alfred Schutz. Rio de janeiro: Zahar, 1979.

SILVA, Joseli Maria. Fazendo geografias: pluriversalidades sobre gênero e sexualidade. In: SILVA, Joseli Maria (org.). Geografias Subversivas: discursos sobre espaço, gênero e sexualidades. Ponta Grossa: Todapalavra, 2009, p. 25-54.

A Cidade dos Corpos Transgressores da Heteronormatividade. In: SILVA, Joseli Maria (Org.) Geografias Subversivas: Discursos sobre Espaço, Gênero e Sexualidade. Ponta Grossa: Editora TodaPalavra, 2009b, p. 135 - 149 .

SOKOLOWSKI, Robert. Introdução à fenomenologia. Tradução de: Alfredo de O. Moraes. São Paulo: Loyola, 2004.

SOUZA, Sandra Duarte de. Revista Mandrágora: Gênero e Religião nos Estudos Feministas. Revista Estudos Feministas, Florianópolis/SC, v. 12 , p. $122-130,2004$. 


\section{LAS EXPERIENCIAS TRAVESTIS Y TRANSEXUALES EN EL ESPACIO RELIGIOSO DE EL PÁTIO DE CULTOS AFROBRASILEÑOS Y MATRIZ AFRICANOS}

RESUMEN: El GÉNERO, LA SEXUALDAD Y LA RELIGIÓN SON temaS POCAS VECES DISCUTIDOS DENTRO DE LA

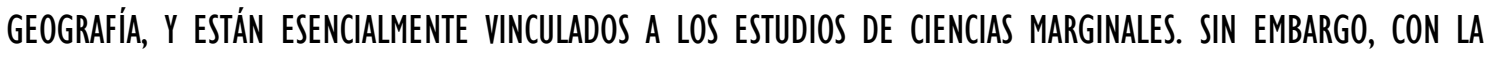
EXPANSIÓN ACTUAL Y DEMOSTRACIONES DE DIFERENTES EXPRESIONES DE GÉNEROS, COMO MANIFESTACIONES DE

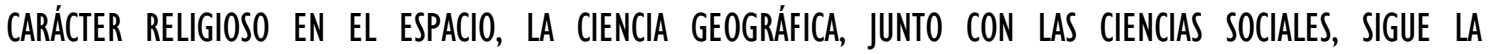
TRAYECTORIA DE LA EMPRESA EN ESTA TEMPORALDAD, CONIRTIÉNDOSE EN UNA CIENCIA INTERDISCIPLINARIA Y

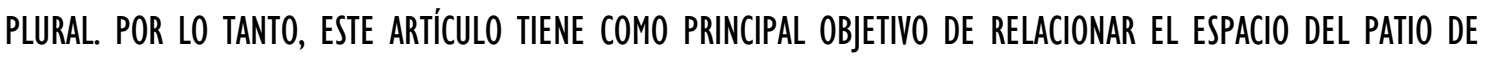
LOS CULTOS AFRO- BRASILEÑA Y ORIGEN AFRICANO COMO LUGAR DE POSIBILIDAD DE LA EXPERIENCIA DE TRAVESTIS Y TRANSEXUALES EXPRESIONES. TENGA EN CUENTA QUE LA RELIGIÓN AFRICANA EN TODAS SUS MANIFESTACIONES, ES PERIFÉrico. La IDEA de QUE el espacio Sagrado de la yarda es las Relaciones de las diferentes EXPRESIONES DE GÉNERO, APARECE A LA SOClEDAD COMO UNA FORMA DE ROMPER LA LíNEA CONTINUA DE LOS NIVELES HETERONORMATIVOS.

PALABRAS-CLAVE: GÉNERO; RELIGIÓN; GEOGRAFía.

THE EXPERIENCES TRANSVESTITES AND TRANSSEXUALS IN SPACE OF TERREIROS CULTS AFRO - BRAZILIAN AND AFRICAN ORIGIN

ABSTRACT: GENDER, SEXUALITY AND RELIGION ARE ISSUES SELDOM DISCUSSED WITHIN THE GEOGRAPHY, AND ARE ESSENTIALLY LINKED TO MARGINAL SCIENCE STUDIES. HOWEVER, WITH THE CURRENT EXPANSION AND 
DEMONSTRATIONS OF DIFFERENT EXPRESSIONS OF GENRES, AS MANIFESTATIONS OF RELIGIOUS NATURE IN SPACE, GEOGRAPHICAL SCIENCE, TOGETHER WITH THE SOCIAL SCIENCES, FOLLOWS THE TRAJECTORY OF THE COMPANY IN THIS TEMPORALITY, BECOMING AN INTERDISCIPLINARY AND PLURAL SCIENCE. THUS, THIS ARTICLE HAS AS MAIN OBJECTIVE TO RELATE THE SPACE OF THE YARD OF AFRICAN -BRAZILIAN CULTS AND AFRICAN ORIGIN AS A PLACE OF POSSIBILITY OF EXPERIENCE AND tRANSVESTITES AND TRANSSEXUALS EXPRESSIONS. PLEASE NOTE THAT tHE AFRICAN RELIGION IN ALL ITS MANIFESTATIONS, IS PERIPHERAL. THE IDEA THAT THE SACRED SPACE OF the YARD IS RELATIONS OF DIFFERENT GENDER EXPRESSIONS APPEARS TO SOCIETY AS A WAY TO BREAK tHE CONTINUOUS LINE OF hETERONORMATIVE STANDARD.

KEYWORDS: GENDER; RELIGION; GEOGRAPHY. 